\title{
PERAN KOMUNIKASI PUBLIK DALAM MENANGGAPI GELOMBANG DISINFORMASI COVID-19
}

\author{
Dody Setyawan $^{*}$, Dekki Umamur Ra'is ${ }^{2}$, Abd. Rohman $^{3}$ \\ 1,2,3 Fakultas Ilmu Sosial dan Ilmu Politik, Universitas Tribhuwana Tunggadewi. \\ *) Korespondensi: dody.setyawan@unitri.ac.id
}

Article Histori:

Accepted: $22 / 9 / 2021$

Review: 4/10/2021

Publish: 31/10/2021

\begin{abstract}
Disinformation has reduced public confidence in the government and scientists in handling Covid-19. These conditions hamper the overall handling of the Covid-19 pandemic. In the context of responding to a global pandemic, disinformation greatly affects the country's response to a global pandemic by undermining trust, creating fear, and sometimes leading to harmful behavior. It is important for policy makers to understand disinformation and how to respond to it. This study uses a literature review approach with data sources coming from several documents that have been verified and have a relationship with the object of study. The stages of the study start from choosing a review topic, finding and selecting appropriate articles, analyzing and synthesizing the literature, and finally presenting a review of the study. the results show that the government should have official information channels with verified, transparent, sustainable and fast sources of information. The government must also provide clear and definite information through official channels and trusted media. The government must also ensure the consistency of information. In addition, the government must maintain a transparent pattern of communication about the situation, actions and risks it takes. The aim is to restore public trust in public institutions, in information that has been conveyed by the government to the public as well as guidelines that have been provided by the government to the public, such as health protocol guidelines and the last is "Prebunk", or be aware of the potential for disinformation before occurred, as part of a public information and communication campaign.
\end{abstract}

Keyword: Covid-19; Public Communications; Public policy; disinformation

\section{PENDAHULUAN}

Disinformasi menyebabkan berkurangnya kepercayaan masyarakat pada pemerintah dan ilmuwan dalam penangan Covid-19. Kondisi tersebut tentu saja menghambat penanganan pandemi Covid-19 secara keseluruhan. Ada tiga macam disinformasi yang menyebar ketika terjadinya pandemi Covid-19. Disinformasi pertama berkaitan dengan kesehatan, kedua teori konspirasi, dan terakhir berkaitan dengan penipuan. Disinformasi yang berkaitan dengan kesehatan misalnya, banyak sekali kita menemukan informasi yang belum terverifikasi kebenarannya tentang penggunaan obat- obatan tertentu untuk digunakan sebagai obat Covid-19.

Para pembuat kebijakan penting untuk memahami apa itu disinformasi dan cara menanggapinya. Dalam konteks untuk merespons pandemi global, disinformasi sangat mempengaruhi respons negara terhadap pandemi global dengan merusak kepercayaan, menciptakan ketakutan, dan terkadang mengarah pada perilaku yang berbahaya. Meskipun "disinformasi" adalah istilah umum yang digunakan untuk menyebut konten informasi yang salah, berbahaya, dan menyesatkan di media dan ekosistem informasi. Ekosistem tersebut 
merupakan kombinasi dari kerangka komunikasi dan tata kelola media (yaitu kelembagaan, hukum, kebijakan, peraturan) dan aktor utama (yaitu pemerintah, perusahaan media tradisional dan sosial, serta jurnalis warga). Mengenai definisi disinformasi hingga saat ini hanya berkisar pada tiga konsep utama untuk menangkap nuansa yang mendasarinya. Ketiga tipe utama tentang disinforamsi dijelakan pada gambar berikut:

Gambar 1. Definisi Tiga Jenis Konten Bermasalah yang Menyebar Secara Online

\begin{tabular}{|c|c|c|}
\hline MISINFORMASI & DISINFORMASI & MALINFORMASI \\
\hline $\begin{array}{l}\text { Ketika informasi } \\
\text { palsu dibagikan, } \\
\text { tetapi tidak ada } \\
\text { bahaya yang } \\
\text { dimaksudkan }\end{array}$ & $\begin{array}{c}\text { Ketika informasi } \\
\text { palsu secara sengaja } \\
\text { dibagikan untuk } \\
\text { menyebabkan } \\
\text { kerugian atau } \\
\text { kerusakan }\end{array}$ & $\begin{array}{l}\text { Ketika informasi asli dibagikan } \\
\text { untuk menyebabkan kerusakan. } \\
\text { Seringkali penyajiannya } \\
\text { dikemas sedemikian rupa untuk } \\
\text { melakukan tindakan yang } \\
\text { merugikan bagi pihak lain atau } \\
\text { kondisi tertentu, ketimbang } \\
\text { berorientasi pada kepentingan } \\
\text { publik }\end{array}$ \\
\hline
\end{tabular}

Sumber: Diadapasi dari Wardle C., Derakshan H. (2017), Information Disorder: Towards an interdisciplinary framework for research and policy making, Council of Europe repot.

Pada saat kepercayaan dan kepatuhan warga terhadap langkah-langkah yang dilakukan oleh pemerintah seperti gerakan mencuci tangan, menjaga jarak, memakai masker, dan Pembatasan Sosial Berskala Besar (PSBB) bermasalah akibat lonjakan disinformasi yang beredar di masyarakat, maka hal tersebut akan merusak respons pemerintah dalam menanggulangi pandemi Covid-19 yang sudah berlangsung satu tahun lebih lamanya. Selain merusak, melonjaknya disinformasi tentang Covid-19 juga akan semakin membahayakan kesehatan masyarakat.

Perawatan medis yang masih belum terbukti, teknik pencegahan yang masih belum sempurna, teori konspirasi, dan informasi lainnya membanjiri Internet dan disebarluaskan oleh pengguna yang kekhawatirannya diperkuat oleh banyaknya informasi yang saling bertentangan. Pertarungan melawan "infodemik" adalah salah satu garis depan prioritas dalam mengelola pandemi Corona Virus (WHO, 2020). Ada beberapa faktor kunci yang memicu terjadinya infodemik. Pertama, publik mencari informasi yang jelas dan pasti dalam situasi yang berkembang dan tidak pasti. Kedua, informasi palsu dan menyesatkan tersebar di dalam jaringan tertutup (walaupun informasi ini belum tentu dapat dipercaya). Ketiga, disinformasi pola penyebarannya semakin terselubung dengan. Disisi lain, publik tidak memiliki keterampilan aliterasi media yang cukup memadai. Sehingga informasi akan diterima tanpa melalui proses penyaringan. Keempat, warga harus menavigasi dan mengevaluasi kelebihan informasi yang sering bertentangan. Kondisi tersebut tentu saja sangat merepotkan bagi publik untuk melakukan pemilahan informasi.

Jenis informasi bermasalah tentang Virus yang beredar di masyarakat menjadi semakin kompleks. Tidak seperti episode disinformasi yang beredar luas sebelumnya, 
banyak konten informasi saat ini memang sengaja dibuat-buat. Banyak ditemukan fakta yang sering dimanipulasi dan teori yang belum terbukti kebenarannya disebutsebut sebagai penemuan dan terobosan dalam menangani pandemi Covid-19. Informasi tersebut sering kali mengeksploitasi ketidakpastian ilmiah. Menurut analisis Reuters Institute tentang sampel konten palsu mengenai Covid-19, ditemukan sebanyak 59\% informasi yang benar telah dimanipulasi, dan sisanya sebanyak 38\% konten tersebut sengaja dibuat-buat (Brennen et al., 2020).

Informasi yang salah tentang Covid-19 telah mengkaburkan anjuran resmi dari lembaga-lembaga kesehatan masyarakat. Hal tersebut semakin sulit untuk diidentifikasi, publik tidak bisa membedakan mana yang fakta, valid, dan palsu. Terkadang, masyarakat melalui media sosial menerima sejumlah informasi tidak berdasar terkait tindakan medis pencegahan Covid-19 yang seolah-oleh berasal dari lembaga kesehatan atau pakar yang ahli dibidangnya. Bahkan, beberapa informasi yang beredar mengaitkan dirinya dengan lembaga kesehatan, lembaga penelitian, dan aktor tertentu sehingga lebih sulit untuk membedakan validitasnya. Sebaliknya, rumor yang meragukan kemanjuran tentang jaga jarak (Social distamcing) atau "informasi" menyesatkan tentang bagaimana penularan terjadi telah meyakinkan beberapa orang untuk melanjutkan aktivitas mereka yang bertentangan dengan pedoman resmi dari pemerintah (Seitz, 2020).

Di banyak negara termasuk Indonesia, pada awal penanganan pandemi Covid-19, pemerintah sering kali memulai komunikasi dengan banyak hal saling tumpang tindih dan terkesan bertentangan antara satu sama lainnya. Baik itu informasi yang disebarkan oleh lembaga pemerintah maupun ahli yang memiliki kapasitas dibidang tersebut. Pola komunikasi tersebut telah menimbulkan keragu-raguan publik terkait Covid-19. Komunikasi yang kurang meyakinkan membawa publik berada dalam ketidakpastian menghadapi pandemi Covid-19. Ketidakpastian dan ketidaktahuan seputar pandemi telah meninggalkan ruang bagi informasi yang salah untuk berkembang biak ketika publik mencari jawaban. Situasi ini semakin diperparah oleh adanya "kesenjangan dalam latar belakang pengetahuan tentang kesehatan yang dimiliki oleh publik". Kondisi tersebut secara tidak langsung mengaskan adanya kebutuhan tentang komunikasi berkelanjutan dan efektif yang perlu dilakukan oleh pemerintah melalui lembaga-lembaga kesehatan negara atau badan-badan yang yang dibentuk secara khusus oleh pemerintah untuk mengani pandemi Covid-19. Idealnya, pola-pola komunikasi tersebut harus dikembangkan jauh sebelum menyebarnya Covid-19.

Kemampuan Pemerintah dalam menutup kesenjangan ini dapat membantu mengurangi atau menghilangkan kecenderungan masyarakat untuk salah mengartikan sifat, perilaku, aktivitas, dan tindakan kesehatan seperti pentingnya desinfektan dan perilaku dalam masa pandemi. Langkah-langkah pencegahan yang sudah diketahui publik dan dikomunikasikan secara aktif oleh pemerintah dan komunitas kesehatan sejak dini, seperti mencuci tangan dan menjaga jarak sosial, akan membentuk kesadaran publik (Jamieson dan Albarracin, 2020). Temuan ini membawa implikasi penting tidak hanya untuk komunikasi yang lebih baik tetapi juga untuk berinvestasi dalam literasi kesehatan yang lebih besar (Moreira, 2018).

Konsekuensi buruk dari misinformasi terlihat jelas dalam perilaku publik ketika merespons pandemi. Dalam banyak kasus, angka kematian yang sangat tinggi akibat Covid-19 dianggap bukan bagian dari peristiwa tersebut. Sebagian besar angka 
tersebut dianggap kematian biasa yang tidak berhubugan dengan kondisi Pandemi. Sehingga publik tetap abai dengan perilaku semestinya ketika pandemi terjadi. Bahkan dalam kajian yang dilakukan oleh Johnson et al. (2020), memperkirakan bahwa Disinformasi sengaja digunakan oleh kelompok-kelompok atau gerakan antivaksinasi begitu vaksin untuk Covid-19 tersedia, yang berpotensi merusak efektivitasnya. Disinformasi yang disebarkan oleh kampanye yang disponsori negara asing secara khusus berupaya untuk melemahkan kepercayaan pada lembaga publik di negara-negara OECD, yang telah pulih hingga $45 \%$ setelah jatuh ke tingkat kepercayaan yang lebih rendah lagi setelah krisis keuangan global 2008 (OECD, 2019) dan juga telah menikmati sedikit dorongan selama pandemi (Edelman, 2020). Kampanye disinformasi ini sering sangat bergantung pada fakta yang dibuat-buat dengan menunjukkan adanya konspirasi, yang dapat lebih mudah berkembang dengan memanfaatkan tingkat kepercayaan yang sudah rendah di antara warga negara di negara-negara sasaran. Sebuah survei Edelman dari sepuluh negara menemukan bahwa hanya $48 \%$ yang memercayai pemerintah mereka sebagai sumber informasi tentang virus (Edelman, 2020). Klaim palsu tentang tindakan, statistik, atau kebijakan otoritas publik, termasuk pemerintah dan organisasi internasional, adalah satu-satunya kategori terbesar (39\%) disinformasi yang diidentifikasi oleh Reuters Institute Study, yang menunjukkan bahwa Pemerintah tidak selalu berhasil memberikan informasi yang jelas dan bermanfaat dan informasi tepercaya untuk menjawab pertanyaan publik yang mendesak (Brennen et al., 2020). ke dalam 5 digit, atau sekitar $1 \mathrm{~cm}$ dari tepi kiri tiap kolom. Pada bagian akhir pendahuluan tuliskan hasil yang diharapkan atau tujuan penelitian dalam artikel ini.

\section{KAJIAN LITERATUR}

COVID-19 adalah krisis kesehatan global yang belum pernah terjadi sebelumnya yang akan memiliki konsekuensi tak terukur bagi kesejahteraan ekonomi dan sosial kita. Tedros Adhanom Ghebreyesus, direktur jenderal Organisasi Kesehatan Dunia, menyatakan "Kami tidak hanya memerangi epidemi; kita sedang melawan infodemik".

Covid-19 adalah penyakit baru, sehingga para ahli pun masih terus mempelajari perilakunya. Akibatnya, banyak orang mengalami kesulitan menemukan informasi terbaru dan hal ini menjadi celah yang dimanfaatkan oknum untuk mendapatkan keuntungan dengan menyebarkan kabar palsu. Di Indonesia, salah satu negara dengan angka kasus Covid-19 tertinggi di Asia, sebuah survei nasional yang dilaksanakan pada tahun 2020 menemukan bahwa antara 64 hingga 79 persen responden tidak dapat mengenali misinformasi di dunia maya. Mayoritas responden di dalam survei yang dilaksanakan oleh Kementerian Komunikasi dan Informatika dan Katadata Insight Center (KIC) ini juga menyatakan media sosial sebagai sumber informasi mereka yang utama (Burhan, 2020).

Informasi yang salah tentang COVID-19 datang dalam berbagai bentuk, dari berbagai macam sumber, dan membuat banyak klaim yang berbeda-beda. Informasi tersebut sering mengkonfigurasi ulang konten yang sudah ada atau benar daripada mengarangnya secara grosir, dan di mana informasi tersebut kemudian dimanipulasi dan diedit dengan alat sederhana (Brennen, et. al., 2020). Menurutnya, keterlibatan tokoh masyarakat terkemuka terus memainkan peran besar dalam menyebarkan informasi yang salah tentang COVID-19. Keterlibatan para tokoh tersebut sangat tinggi di berbagai platform media sosial.

Penyebaran informasi yang salah pada platform media sosial lebih cepat daripada penyebaran Penyakit Virus Corona (Covid- 
19) itu sendiri dan dapat menimbulkan konsekuensi yang mengancam sistem penanganan kesehatan di tengah bencana Covid-19. Penyebaran informasi yang salah pada media sosial dapat merusak respon individu terhadap Covid-19 (Barua, dkk., 2020). Selain itu, disinformasi yang menyebar selama pandemi Covid 19 membuat masyarakat takut dan panik (Rahmawati, dkk., 2021).

Sedangkan Kajian lain yang dilakukan oleh Loomba, dkk., (2021) tentang hubungan misinformasi dengan tingkat kemauan publik dalam menerima vaksinasi. Kajiannya membuktikan bahwa misinformasi sangat berpengaruh terhadap keputusan seseorang dalam menerima vaksinasi. Kajian tersebut dilakukan di Inggris dan Amerika Serikat. Hasilnya menunjukkan bahwa kesalahan informasi yang terdengar ilmiah sangat kuat kaitannya dengan tingkat penurunan public. untuk menerima vaksinasi.

Dari gambaran tersebut maka keterlibatan pemerintah melalu peran komunisi publiknya sangat penting. Tugas pemerintah adalah mengelola "infodemik" dengan baik. Jika tidak di Kelola dengan baik maka akan memberikan tantanngan yang luar biasa bagi penangan pandemik Covid-19. Bukti tersebut ditunjukkan oleh hasil kajian yang dilakukan oleh Lovari (2020). Dalam kajiannya yang dilakukan di Italia, Lovari, menyoroti dinamika pandemikn Covid19 yang berdampak pada komunikasi pandeminya. Italia mengalami erosi progresif kepercayaan terhadap lembaga publik dan keadaan umum krisis informasi mengenai masalah kesehatan dan sains. Bagi Lovari, intervensi cepat terhadap "infodemik" melalui komunikasi public dengan meningkatkan visibilitas dan keandalan komunikasi kesehatan masyarakat, upaya terkoordinasi yang melibatkan berbagai lembaga, media, dan perusahaan platform digital tampaknya masih diperlukan untuk mengurangi dampak misinformasi, karena menggunakan strategi multisaluran membantu menghindari peningkatan kesenjangan sosial dan teknologi di masa krisis.

Ketidakmampuan negara dalam mengelola infodemik memalui peran komunikasi publiknya tentu akan memberatkan tugas dan kewajiban pemerintah dalam merespon Covid -19. Disinformasi yang terjadi sama cepatnya dengan penyebaran Covid-19 itu sendiri. Banyak variable yang menyebabkan hal itu terjadi salah satunya seperti yang disampaikan oleh Lovari (2020). Selain itu ketidak hadiran negara dalam mengimbangi inforamsi yang tidak tervalidasi akan semakin memberikan ruang terjadinya disinformasi. Dampaknya merosotnya kepercayaan publik terhadap otoritas pemerintah dalam menganni pandemik.

Beberapa negara telah berhasil mengurangi tingkat infeksi COVID-19 mereka lebih awal, sementara yang lain kewalahan. Alasan perbedaannya kompleks, tetapi keberhasilan respons sebagian bergantung pada kecepatan dan skala intervensi pemerintah dan bagaimana masyarakat menerima, memahami, dan bertindak berdasarkan informasi yang diberikan oleh pemerintah dan lembaga lain. Meskipun tidak ada strategi komunikasi 'satu ukuran yang cocok untuk semua' untuk menyampaikan informasi selama krisis berkepanjangan (Hyland-Wood, dkk., 2021).

\section{METODE PENELITIAN}

Penelitian ini menggunakan pendekatan kajian pustaka. Kajian pustaka merupakan survei artikel ilmiah, buku, dan sumber lain yang relevan dengan masalah tertentu, bidang penelitian, atau teori, dan dengan demikian, memberikan deskripsi, ringkasan, dan evaluasi kritis dari karyakarya tersebut. Kajian pustaka dirancang untuk memberikan gambaran umum tentang sumber yang telah dikumpulkan dalam rangka mengkaji topik tertentu dan untuk menunjukkan kepada pembaca, bagaimana kajian penulis cocok dengan bidang studi yang lebih besar. Kajian ini 
dilakukan secara sistematis dengan tujuan untuk memberikan daftar selengkap mungkin dari semua studi yang belah diterbitkan dan tidak diterbitkan yang berkaitan dengan bidang subjek tertentu. Sumber data yang digunakan dalam kajian ini berasal dari beberapa dokumen yang telah diverifikasi dan memiliki keterkaitan yang kuat dengan objek kajian. Tahapantahapan dalam mode ini dimulai dari memilih topik ulasan, mencari dan memilih artikel yang sesuai, menganalisis dan mensintesis literatur, dan terakhir menyajikan ulasan kajian.

\section{HASIL DAN PEMBAHASAN}

Dalam kajian yang dilakukan oleh City University of London (2020) tentang disinformasi dikaitkan dengan susdut pandang perilaku dan kognitif, menemukan bahwa gelombang disinformasi berkontribusi pada kelebihan informasi yang dapat memenuhi informasi penting, yakni situasi, di mana warga dihadapkan dengan sejumlah informasi yang semakin bertentangan, yang menuntut adanya upaya lebih besar dari pemerintah untuk menavigasi dan bersaing dalam memperebutkan perhatian audiens yang terbatas. Implikasinya bagi kebijakan publik adalah bahwa peningkatan volume informasi resmi dan jujur belum tentu lebih efektif kecuali konten ini dibuat lebih menarik dan disampaikan ke berbagai khalayak melalui saluran pilihan mereka, dan dengan pemahaman tentang bias perilaku dan psikologis. Hal ini sangat penting bagi khalayak muda, yang cenderung mengakses berita terutama melalui media sosial.

Sehubungan dengan penggunaan saluran yang disukai, sebuah studi di Misinformation Review merekomendasikan agar pejabat kesehatan publik berusaha secara aktif untuk menyebarkan pesan dalam apa yang oleh penulis digolongkan sebagai "media konservatif," mencatat bahwa khalayaknya kurang percaya dan lebih berisiko dari informasi yang salah, apalagi dikaitkan dengan umur (Jamieson dan Albarracin, 2020). Pendekatan semacam itu penting untuk memastikan pesan faktual dan pesan penting menjangkau semua khalayak. Ini juga secara efektif memanfaatkan saluran di mana mereka memperoleh informasi, karena kelompok yang berbeda cenderung mempercayai saluran media yang sejalan dengan kebiasaan dan pandangan mereka.

Singkatnya, disinformasi mengancam usaha, ketepatan dan kepatuhan pulik terhadap tindakan darurat yang diberlakukan oleh pemerintah dalam menagani Corona Virus. Disinformasi juga menimbulkan tantangan bagi pemulihan ekonomi dan sosial di masa depan. Timbulnya polarisasi dan ketidakpercayaan publik yang berasal dari disinformasi akan memiliki implikasi negatif dalam jangka panjang yang mempengaruhi tindakan pemerintah, demokrasi, dan pertumbuhan inklusif Negara.

Respons yang berhasil terhadap pandemi memerlukan upaya multistakeholder yang terkoordinasi untuk mengatasi disinformasi di sekitarnya, dengan kepemimpinan publik yang jelas. Komunikasi yang strategis dan transparan harus menjadi salah satu tindakan pertama bagi lembaga publik di semua tingkatan. Komunikasi yang strategis dan transparan merupakan bagian dari Komunikasi publik yang bisa dipahami sebagai setiap kegiatan atau inisiatif komunikasi yang dipimpin oleh lembaga publik untuk kepentingan publik. Berbeda dengan komunikasi politik, yang terkait dengan debat politik, pemilu, atau individu tokoh politik dan partai. Kegiatan komunikasi publik dapat mencakup pemberian informasi, serta konsultasi dan dialog dengan pemangku kepentingan. Komunikasi yang strategis dan transparan dapat dimanfaatkan untuk beberapa tujuan terkait dengan disinformasi, seperti 1) Melibatkan warga dalam membentuk respons kolektif terhadap infodemik; 2) Memberikan 
informasi yang benar dan akurat kepada warga; 3) Menyingkirkan informasi palsu atau menyesatkan; 4) Mendukung pemahaman yang lebih baik tentang etika publik, termasuk ketakutan, kekhawatiran, dan harapan; dan 5)Mendidik publik tentang cara mengkonsumsi dan membagikan konten secara bertanggung jawab.

Dalam praktiknya, komunikasi publik mencakup penyediaan informasi untuk kepentingan publik yang faktual, transparan, dan terpisah dari komunikasi politik. Fitur terakhir ini sangat relevan dengan konteks polarisasi dan fragmentasi politik yang tinggi saat ini di Indonesia, di mana beberapa kelompok mungkin lebih cenderung berpaling dari informasi resmi jika mereka menganggapnya dipolitisasi.

Dalam konteks Covid-19, jenis intervensi ini memberikan keuntungan ganda yaitu mendukung pelaksanaan tindakan darurat yang efektif dan memenuhi kebutuhan akan informasi yang jelas dan pasti. Komunikasi publik juga dapat dilakukan dengan cepat karena hampir semua pemerintah memiliki kantor pers dan saluran digital. Struktur ini sangat penting dalam konteks di mana mekanisme atau peraturan yang sudah ada sebelumnya terhadap disinformasi tidak ada atau lemah. Agar efektif dan menumbuhkan kepercayaan publik kepada pemerintah, setiap kegiatan yang dilakukan dalam hal ini harus berpedoman pada prinsip-prinsip transparansi, integritas, akuntabilitas, dan partisipasi pemangku kepentingan.

Pemerintah harus membuat standar dan pola komunikasi yang baku serta kuat. Karena standar dan pola yang baku dalam komunikasi publik adalah kunci yang efektif dalam memerangi disinformasi dan mendapatkan kepercayaan publik. Standar komunikasi publik yang baku bisa menjadi salah satu alat manajemen krisis dan penyampaian kebijakan. Dengan demikian, standar pola komunikasi publik yang baku, perannya sangat penting untuk diformalkan dan disesuaikan dengan sumber daya yang dimiliki pemerintah. Melalui saluran resmi yang telah dibuat, pemerintah bisa menjadi "sumber informasi yang terverifikasi, transparan, berkelanjutan, dan cepat" bagi masyarakat. Dampaknya, publik semakin percaya dengan pemerintah dan pemerintah bisa memerangi masalah disinformasi. Dampak lainnya adalah pemerintah tidak memberikan celah terhadap penyebaran informasi yang telah diisi (dicampur) dengan narasi palsu.

Mengapa penting untuk menyusun pola komunikasi seperti itu?. Ada banyak fakta yang menunjukkan bahwa komunikasi yang salah arah atau tidak konsisten berisiko mengikis kepercayaan publik dan menjadi kontraproduktif. Pemerintah dan lembaga-lembaga terkait dapat melakukan kesalahan yang lebih besar dan bisa memperkuat efek jangka panjang disinformasi jika tidak bisa melakukan komunikasi yang memadai dan menahan informasi penting bagi publik terkait pandemi Covid-19. Untuk mencapai praktek komunikasi publik yang berdampak positif bagi publik dan dalam rangka merespons pandemi Covid-19 dan infodemik, maka pemerintah bisa melakukan pendekatanpendekatan yang direkomendasikan OECD (2020) berikut ini:

\section{Konsistensi dan Ketepatan Waktu Berkomunikasi}

Melalui komunikasi publik, pemerintah dapat mengurangi kemungkinan terjadinya disinformasi dengan segera menyebarluaskan informasi yang akurat. Selama periode ini, pemerintah bisa memberikan briefing kepada publik dengan memberikan informasi harian yang terus diperbaharui. Pada saat yang sama, melalui komunikasi publik, pemerintah bisa menyanggah kesalahan berbagai macam informasi yang berkembang di masyarakat. Melaluinya, pemerintah secara tidak langsung juga bisa melakukan pemantauan dan penilaian yang 
terus menerus terhadap berbagai macam konten berisiko dan perlu dibantah. Prinsipnya, dalam konteks ini informasi yang dikeluarkan oleh pemerintah dan berbagai macam lembaga negara harus saling menguatkan. Narasi informasi yang dibangun harus konsisten dan satu suara.

\section{Membangun Komunikasi Partisipatoris}

Menanggapi infodemik membutuhkan upaya seluruh masyarakat untuk mempertahankan ekosistem informasi yang sehat. Pemerintah bisa melibatkan komunitas medis dan ilmuwan ketika menyebarkan informasi penting kepada warga dan mencegah mereka dari klaim yang tidak terverifikasi dan palsu. Bekerjasama dengan media dan akademisi adalah salah satu cara terbaik untuk menyusun formulasi melawan disinformasi. Kadang-kadang, dalam paraktiknya pemerintah juga harus membuat gugus tugas multistakeholder sebagai bagian tak terpisahkan dari kerj-kerja pemerintah. Melaluinya, dalam berkomunikasi dapat memungkinkan terjadinya dialog dua arah secara langsung dengan warga guna menanggapi kebutuhan dan mendapatkan saran serta masukan yang bisa digunakan oleh pemerintah. Dalam situasi ini pemerintah harus membuka ruang dialog seluas-luasnya dengan publik. Pemerintah bisa melakukannya melalui berbagai macam platform yang di desain secara khusus, seperti media sosial, chanel youtube, influencer atau pola-pola komunikasi konvensional yang biasa dilakukan namun efektif. Tujuannya agar publik dapat memperoleh informasi akurat sehingga dapat membangun kesadaran kolektif. Pemerintah juga harus memberi ruang kepada publik tanpa harus merasa tersaingi untuk juga terlibat dalam kampanye penyebaran informasi dengan memaksimalkan segala potensi kreativitas publik.

\section{Mengantisipasi dan Mengoreksi adanya disinformasi.}

Metode ini menggunakan pendekatan pencegahan dan mengoreksi daripada memeranginya. Saya menyebutnya dengan istilah "pre-bungking", atau pre-emptive dengan cara mengekspos publik melalui sejumlah dosis kecil informasi yang salah dengan cara menyoroti alasan mereka yang salah, sehingga dapat membentengi audien dari konten palsu ketika mereka terpapar darinya (Roozenbeek et al, 2020). Cara kerja ini sama dengan cara kerja vaksin yang disuntikkan ke tubuh manusia. Seperti yang kita ketahui Vaksin adalah zat yang berisi virus yang telah dilemahkan atau dimatikan. Tujuan vaksin adalah merangsang tubuh untuk membangun sistem kekebalan tubuh dari serangan virus berbahaya. Spanyol adalah salah satu negara yang mengadopsi pendekatan ini, di mana ia menginformasikan kepada publik tentang "kemajuan ilmiah dan kemungkinan adanya tipuan dan rumor yang mungkin muncul," berdasarkan saran dari hasil analisis para ilmuwan yang mengerti tentang Covid-19 dan pakar lainnya.

\section{Melakukan Intervensi Berbasis Bukti.}

Komunikasi strategis dibangun atas pemahaman yang kuat terhadap tantangan informasi yang timbul dari sikap publik dan cara mereka mengkonsumsi informasi. Misalnya, sikap publik terhadap pembawa pesan membawa implikasi untuk berkomunikasi tentang virus: $85 \%$ responden survei di 10 negara mengaku lebih suka mendengar dari para ilmuwan daripada dari politisi (Edelman, 2020). Hal ini menunjukkan bahwa bukti sama pentingnya dengan isi pesan publik. Di beberapa negara Eropa seperti Belgia dan Portugal, penyampaian informasi publik tentang pandemi disampaikan oleh para ilmuwan yang berkompeten. Selain itu, membuka seluasluanya akses informasi tentang Covid-19 kepada publik juga tak kalah pentingnya.

\section{Membangun Transparansi komunikasi.}

Selama terjadinya krisis, mengungkapkan tentang ketidakpastian sebuah masalah dan keputusan besar yang akan diambil oleh pemerintah adalah yang sangat penting. Menahan informasi penting bagi publik 
atau tidak terbuka tentang apa yang perlu diketahui, tidak perlu dicurigai, tidak perlu ditakuti dan menimbulkan ketidakpercayaan dalam penganan pandemi Covid-19, hal tersebut sama-sama berbahayanya bagi ketertiban umum dan kemanjuran tindakan darurat yang dilakukan oleh pemerintah serta rentan terhadap penyebasran disinformasi.

Menjaga transparansi informasi dan proaktif menyebarkan informasi kepada warga semakin diakui sebagai salah satu cara yang paling efektif untuk mendukung implementasi kebijakan dan memulihkan kepercayaan publik, sambil menyanggah rumor dan narasi-narasi palsu yang berkembang di masyarakat. Selain menangkal disinformasi, ia juga menyediakan sarana yang tepat untuk akuntabilitas pemerintah atas penanganan pandemi Covid-19.

\section{Mengadopsi pendekatan Komunikasi Strategis.}

Pendekatan strategis memerlukan penyelarasan tujuan dan pendekatan kegiatan dengan tujuan akhir memerangi disinformasi. Pendekatan ini juga melibatkan pembentukan struktur yang tepat, mendedikasikan sumber daya manusia, dan keuangan untuk memastikan respons yang efektif dan terkoordinasi, dengan kemampuan untuk melakukan penyesuaian terhadap tuntutan keadaan mengingat lanskap disinformasi yang terus berkembang.

Selain rekomendasi tersebut, ada bebrapa hal yang perlu diperhatikan oleh pemerintah untuk memperkuat peran Komunikasi publiknya. Pemerintah (pihak otoritas) harus memiliki kemampuan untuk memahami konsep mis-, dis-, dan malinformasi. Kemampuan memahminya dapat diterapkan pada berbagai contoh empiris dan, jika diterapkan dengan benar, dapat berguna dalam memerangi infodemik COVID-19.

Singkatmya apa yang disampaikan Brennen, et. al (2020) berikut layak untuk diperhatikan. Pemerintah harus memiliki kemampuan untuk menganalisis semua jenis informasi penting dalam pertempuran melawan infodemik COVID-19; Pemerintah harus menggunakan pendekatan ilmiah yang diperlukan agar metode yang berbeda tidak digunakan oleh penelitian yang berbeda. Pemerintah harus memperhatikan "informasi yang salah", sebagai istilah umum, yang dapat membingungkan harus dihentikan penggunaannya. Definisi ilmiah yang jelas tentang jenis informasi akan dibutuhkan di masa mendatang. Pemerintah harus ingat, baghwa informasi yang salah adalah fenomena yang diabaikan yang melibatkan konfigurasi ulang kebenaran.

\section{PENUTUP}

Disinformasi adalah masalah kompleks yang dapat mempengaruhi pembuatan kebijakan dan interaksi pemerintah dengan warga. Bagaimana cara disinformasi dibuat dan disebarkan juga terus berubah. Teknologi AI dan Deepfake misalnya, di masa depan akan sangat mempengaruhi penyebaran disinformasi kepada publik Ke depan, pemerintah perlu fokus pada bagaimana merespons tantangan ini, mengemas pola komunikasi publik serta memanfaatkan teknologi baru dengan cara berpegang pada prinsip-prinsip pemerintahan terbuka.

Transparansi dan penyediaan informasi merupakan sarana dan tujuan penting dari ekosistem media dalam komunikasi publik yang terbuka. Informasi yang berlebihan merupakan tantangan tambahan di era digital. Di era berita tanpa henti yang disajikan di berbagai perangkat, "ledakan pengetahuan dan informasi" yang dipercepat oleh perkembangan teknologi digital dapat membatasi kemampuan orang untuk memprioritaskan dan mengontekstualisasikan apa yang paling penting atau relevan.

Komunikasi publik hanyalah salah satu dari berbagai tanggapan yang dapat digunakan untuk melawan disinformasi. 
Selain itu, komunikasi publik merupakan salah satu elemen kunci dari agenda pemerintahan terbuka. Mengatasi masalah ini juga bergantung pada platform digital dan pasar media di mana informasi dibingkai dan disampaikan, serta pada konsumen akhir dari informasi tersebut.

Komunikasi publik memiliki peran yang sangat penting dalam memerangi disinformasi Covid-19. Komunikasi publik berfungsi sebagai sarana untuk menyampaikan informasi yang transparan, jujur, dan akurat tentang Covid-19 serta memungkinkan pemerintah untuk memahami dan berinteraksi dengan warga negara terkait pandemi yang sedang terjadi. Komunikasi Publik menjadi sangat penting, terutama dalam konteks di mana narasi yang ambigu dan bertentangan menantang kebijakan dan data resmi yang dimiliki pemerintah. Sehingga, menjangkau warga melalui saluran dan platform yang biasa mereka gunakan untuk menerima informasi menjadi prioritas yang penting. Maka, mutlak bagi pemerintah untuk memiliki saluran informasi resmi dengan sumber informasi yang terverifikasi, transparan, berkelanjutan, dan cepat.

Dengan demikian, untuk menanggapi gelombang disinformasi Covid-19, maka pemerintah harus melakukan beberapa hal. Pertama, memberikan informasi yang lebih jelas dan pasti melalui saluran resmi dan media yang sudah terpercaya; Kedua, pastikan adanya konsistensi informasi, walaupun informasi tersebut masih bersifat tentatif, dan pastikan seluruh otoritas publik untuk berbicara dalam satu suara serta mengurangi informasi yang berlebihan; Ketiga, memelihara (menjaga) pola komunikasi yang transparan tentang situasi, tindakan dan risiko yang diambil pemerintah. Tujuannya untuk memulihkan kepercayaan masyarakat terhadap lembaga-lembaga publik, terhadap informasi yang telah disampaikan pemerintah kepada publik serta panduanpanduan yang telah diberikan oleh pemerintah kepada publik, seperti panduan protokol kesehatan; dan Keempat, "Prebunk", atau mewaspadai adanya potensi disinformasi sebelum terjadi, sebagai bagian dari kampanye komunikasi dan informasi publik.

Strategi komunikasi yang efektif adalah proses dua arah yang melibatkan pesan yang jelas, disampaikan melalui platform yang tepat, disesuaikan untuk audiens yang beragam, dan dibagikan oleh orang-orang yang dipercaya. Pada akhirnya, keberhasilan jangka panjang tergantung pada pengembangan dan pemeliharaan kepercayaan publik.

\section{DAFTAR PUSTAKA}

Barua, Z., Barua, S., Aktar, S., Kabir, N., \& Li, M. (2020). Effects of misinformation on COVID-19 individual responses and recommendations for resilience of disastrous consequences of misinformation. Progress in Disaster Science, 8, 100119.

Brennen, J. S., Simon, F. M., Howard, P. N., \& Nielsen, R. K. (2020). Types, sources, and claims of COVID-19 misinformation (Doctoral dissertation, University of Oxford).

Brennen, J. S., Simon, F., Howard, P. N., \& , R. K. (2020). Types, sources, and claims of COVID-19 misinformation. Reuters Institute, 7(3), 1.

Burhan, F. A., (2020), Survei KIC: Masyarakat Lebih Percaya Medsos Ketimbang Situs Pemerintah. https://katadata.co.id/desysetyowati /digital/5fb7b04fa5eb9/survei-kicmasyarakat-lebih-percaya-medsosketimbang-situs-pemerintah. Diakses pada 24 September 2021

City University of London (2020), COVID-19 Information Overload leads to simple but unhelpful choices, https://www.city.ac.uk/news/2020/ april/covid-19-information-overload- 
leads-to-simple-but-unhelpful-choices (accessed on 19 Agustus 2021)

Edelman (2020), Edelman Trust Baromter 2020,

https://www.edelman.com/sites/g/f iles/aatuss191/files/2020-

03/2020\%20Edelman\%20Trust\%20Bar ometer $\% 20$ Coronavirus $\% 20$ Special $\% 2$ 0Report_0.pdf (accessed on 22 Agustus 2021).

Hyland-Wood, B., Gardner, J., Leask, J., \& Ecker, U. K. (2021). Toward effective government communication strategies in the era of COVID-19. Humanities and Social Sciences Communications, 8(1), 1-11.

Jamieson, K. H., \& Albarracin, D. (2020). The Relation between Media Consumption and Misinformation at the Outset of the SARS-CoV-2 Pandemic in the US. The Harvard Kennedy School Misinformation Review.

Johnson, N. F., Velásquez, N., Restrepo, N. J., Leahy, R., Gabriel, N., El Oud, S., ... \& Lupu, Y. (2020). The online competition between pro-and antivaccination views. Nature, 582(7811), 230-233.

Loomba, S., de Figueiredo, A., Piatek, S. J., de Graaf, K., \& Larson, H. J. (2021). Measuring the impact of COVID-19 vaccine misinformation on vaccination intent in the UK and USA. Nature human behaviour, 5(3), 337-348.

Lovari, A. (2020). Spreading (dis) trust: Covid-19 misinformation and government intervention in Italy.
Media and Communication, 8(2), 458461.

Moreira, L. (2018). Health literacy for people-centred care: Where do OECD countries stand?.

Newman, N., Fletcher, R., Schulz, A., Andi, S., Robertson, C. T., \& Nielsen, R. K. (2019). Reuters Institute Digital News Report 2019. Reuters Institute for the Study of Journalism.

O. E. C. D. (2020). Transparency, communication and trust: The role of public communication in responding to the wave of disinformation about the new Coronavirus.

Pennycook, G., McPhetres, J., Zhang, Y., Lu, J. G., \& Rand, D. G. (2020). Fighting COVID-19 misinformation on social media: Experimental evidence for a scalable accuracy-nudge intervention. Psychological science, 31(7), 770-780.

Rahmawati, D., Mulyana, D., Lumakto, G., Viendyasari, M., \& Anindhita, W. (2021). Mapping Disinformation During the Covid-19 in Indonesia: Qualitative Content Analysis. Jurnal ASPIKOM, 6(2), 222-234.

Seitz, A. (2020). Virus Misinformation Flourishes in Online Protest Groups.

Wardle, C., \& Derakhshan, H. (2017). Information disorder: Toward an interdisciplinary framework for research and policy making. Council of Europe, 27.

WHO, E. (2020). Novel Coronavirus (2019$\mathrm{nCoV})$ Situation Report-39. 